THEMATIC SECTION: THE RIGHT TO PUBLIC EDUCATION, DEMOCRACY, AND SOCIAL

STRUGGLES

\title{
Education and labor in Brazil: workers' education in the perspective of the capital
}

\section{Jaime Hillesheim ${ }^{1}$}

https://orcid.org/0000-0002-2798-6418

\author{
Adir Valdemar Garcia ${ }^{2}$ \\ https://orcid.org/0000-0001-7805-4242
}

${ }^{1}$ Federal University of Santa Catarina, Department of Social Work, Graduate Program of Social Work, Florianópolis, SC, Brazil.

${ }^{2}$ Federal University of Santa Catarina, School of Educational Sciences, Department of Specialized Studies on Education, Florianópolis, SC, Brazil.

\section{Education and labor in Brazil: workers' education in the perspective of the capital}

Abstract: This article is grounded on the critic social theory, and analyzes the content presented in the Brazilian National Plans of Education (2001-2010 and 2014-2024) and the Education Development Plan (2007) regarding the relationship between education and work. Documentary research aimed to identify the political perspectives that establish this relationship in a context of crisis of capitalism and regression of rights around the world and, particularly, in Brazil. The results show that updating and strengthening education is essential to prepare the workforce in line with the new needs of the sphere of production, a relation that is often disguised by the discourse and defense of citizenship, law, and humanistic values.

Keywords: Education. Labor. National Plan of Education. Education development plan.

Submitted on January 28, 2019. Approved on April 16, 2019. Reviewed on June 05, 2019.

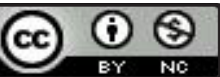

(C) The Author(s). 2019 Open Access This article is distributed under the terms of the Creative Commons Attribution-NonCommercial 4.0 International License (http://creativecommons.org/licenses/by-nc/4.0/), which permits use, distribution, and reproduction in any medium, since it's for non-commercial purposes, and provided you give appropriate credit to the original author(s) and the source, provide a link to the Creative Commons license, and indicate if changes were made. 


\section{Introduction}

This article discusses the relationship between education and work, within the context of regression of rights in Brazilian society, marked by its condition of peripheral and dependent economy. In the face of the intense and lasting effects of the capitalist crisis, principles that guide the so-called 'democratic rule of law' are relativized to ensure the expanded reproduction of capital. This relativization implies the destruction of democratic advances and the maintenance of high levels of social inequality and poverty, despite Brazil being one of the largest economies in the world. In this context, the right to public education is always subjected to the interests of the labor market, characterized by increasingly flexible and precarious relations. Therefore, the direction of the public policy of education, as expected in bourgeois sociability, responds to the objective and subjective needs of the reproduction of the workforce as required for the development of the mode of production governed by capital.

The critical analysis of this relationship between education and work in the current context of Brazilian society needs to consider the global dynamics of capitalism. It also needs to consider the proposals, objectives, and goals that are stated in the different governmental management and planning instruments. The elements in these instruments conceal real needs, both of capital and labor while expressing contradictions inherent in the disputes of different projects of society.

The research presented in this article examined official documents produced by schools and by local (12 municipalities), state (Santa Catarina), and federal governments, in order to understand the paths designed for Brazilian public education to confront poverty and social inequality. The documents analyzed addressed education management and planning, considering the period from 2003 to $2015^{1}$. Among the issues raised during the research process, stands out the relationship between education and work, a binomial always present in the propositions that consider education policy as an essential mediation to fight poverty and social inequality in Brazil. This article presents reflections about this relationship, based on the content of the National Plan of Education (PNE) (2001-2010 and 2014-2024) and the Education Development Plan (PDE) (2007).

This exploratory research adopts a quantitative-qualitative approach and a critical perspective. It seeks to relate the studied object with its multiple determinations based on theoretical categories such as work, education, ideology, human emancipation, state, social policy, and others that are part of the critical social theory.

The article firstly presents reflections on the literature addressing the relationship between education and work, considering the context of bourgeois sociability. Then a discussion follows on how this relationship is referenced in the set of documents examined. Finally, the article presents the conclusions elaborated based on the research findings.

\section{Education, work, and requirements posed by the process of capital (re)production}

The analysis of education, from a Marxian perspective, starts from the critique of political economy. Thus, this study gives evident importance to the relationship between work and education in the mode of production ruled by the capital. Within the framework of bourgeois sociability, workers' education is irrevocably connected to productive interests, as a way of forging an objective and subjective workforce that responds to the demands of the production and reproduction of life within capitalist society.

Despite the criticisms toward the social processes that produce education for and by the alienated and alienating work, Marx (2013) defends that education related to work is an important mediation so workers can take ownership of the totality of the productive process. In this sense, the knowledge obtained may serve as an instrument of struggle, in a way that workers can control their production, which is an essential condition to achieve structural transformations of the capitalist social order. It is crucial to be aware of the contradiction manifested in this relationship. In the context of the capitalist mode of production, workers are alienated from their activity while the knowledge and consciousness, produced by the human activity at work, are appropriated privately by capital to enhance the processes of extracting surplus value. This historical condition indicates that education must be thought of as an entire dimension, as opposed to a mere instruction of workers to perform isolated or grouped tasks, as demanded in the different forms of organization of work, in the different production models. Therefore, education is not limited to technological knowledge, characterized by the production of partial knowledge to solve immediate demands of the productive processes. Education must be faced beyond schooling, based on an omnilateral formation embodied in work understood as human self-activity, in which and by which the social being is founded and developed (Lukács, 2013; Marx, 2013). This work is very different from the social and historical form of alienated labor, commodity labor, whose dynamics are based on the exploitation of the workforce, through which the worker can (but not always) guarantee their subsistence. 
Lukács (2013, p. 204) clarifies that, through the development of the social being "new forms of work emerge, bringing new forms of division of labor, which in turn result in new ways for humans to establish practical relationships, which then, ... retrace their own constitution". This development implies assimilation of accumulated knowledge, critical positioning in the face of theses that claim to be the truth, and construction of new answers to social needs. Thus, the process of 'humanization' of the human race itself is educational. It can, however, be directed toward strengthening certain world perspectives and responding to the needs of the current ontologically emerging social form as well as responding to the interests of the coexisting classes. Through work activity, therefore, the social being develops new capacities that respond to ever-renewed needs, in infinite processes. Therefore:

the consequences of the work are beyond what was immediately and consciously invested on it. These consequences bring to the world new needs and new capacities to satisfy them within the objective possibilities of each education, no matter how well determined. The 'human nature' does not limit this development beforehand (Lukács, 2013, p. 303).

According to the Marxian perspective, the educational process occurred in the realization of the work as human self-activity, associates this 'self-activity' with autonomous knowledge. This work, however, does not have the purpose of serving class interests, as occurs within the capitalist society. For Marx, an emancipated society presupposes that free and associated workers have conscious control of the process of material production:

The design of the social process of life, or the form of the material process of production, only is free of its mystic veil of fog when it stands as a product of freely socialized people under their conscious, planned control. For that to happen, a material basis of society is required or a row of material conditions of existence that are primordial products of a long and painful history of development (Marx, 2013, p. 154).

However, there is no way to envisage the possibility of producing autonomous knowledge only as a result of a type of sociability after capitalism, founded on a planned economy whose processes and their results are appropriated by the workers as a driving force of the process of humanization. It is necessary to understand education as a necessary mediation for the construction of social processes that can cause tensions and ruptures with the material basis that sustains and allows the reproduction of the current capitalist mode of production. It is also necessary to identify the set of strategies the capital uses to turn education into an essential instrument to solve problems triggered by the advances of the productive forces. These are problems related to a mismatch between the existing workforce profile and the new demands imposed by the advances of productive forces, in particular by innovation in production processes. These capital needs determine the structure, content, and dynamics of educational policies in different historical conditions and moments. On the other hand, there are possibilities manifested in the different processes of the movement of reality, potentializing actions that confront the established structures, and these possibilities must be recognized. Even when education is considered as the instruction organized in teaching institutions at different levels - in order to find social legitimacy in the face of different social interests in confrontation - it also incorporates contradictory demands that give dynamism to pedagogical processes. In this direction it is possible to affirm that there is neither an education nor educational policies impervious to class struggles. Moreover, education, from a broader perspective, occurs in social spaces other than at school, in and through the organizational processes of the classes. Therefore, from the workers' point of view, an education that confronts what is established and supports the programmatic actions of organizations representing the class may and must be born, evolving in the political struggle based on the assumptions and foundations of the critical political economy inaugurated by Marx (2013). This education has the power to unleash processes that could rarely be released within traditional education controlled by the bourgeois state apparatus. Formal education, helps enormously in material production, meeting real needs of the productive world through training the workforce from an operational point of view (mastery of new technologies, or assimilation of new forms of work organization, for example). It also has a centrality in shaping the subjectivity of the worker (and future generations of workers), in line with the values and forms of consciousness that corroborate the processes of reproduction of the social form of capitalism. By identifying education as a complex social system that evolves in the humanization process, Lukács (2013), indicates the need to understand it deeply. He warns that such a complex system cannot be understood in isolation, apart from the other complex systems that form the social being, even if the system is at the center of everything. When ignoring the other complex systems, there is a risk of distorting the "authentic and broad lines of total development" (Lukács, 2013, p. 310) of the social being. The heart of the analysis "must be the emergence and 
change of economic categories," given that "the economy differs ontologically from each of the other complexes." (Lukács, 2013, p. 310) ${ }^{2}$. In the same line, Lukács (2013, p. 313) states that:

the development of the productive forces - according to its essence - is identical to the elevation of human capacities. However, as occurs with the social needs, from the perspective of the phenomenon, the development of productive forces may also cause degradation, deformation, or self-alienation of the human being.

Therefore, "we must verify what consequences the development of the productive forces has for the construction and the dynamics of society." (Lukács, 2013, p. 315). This article seeks to understand the roles of education and its connection to the world of work, in the context of Brazilian capitalism, characterized as dependent and peripheral.

This relationship is determined by the antagonisms that emerge from the conflicts inherent in the private appropriation of the surplus-value produced by the working class. Within the global capital system, this relationship is shaped so that education policies serve as an instrument not only for building the labor profile required by the labor market but also as a mechanism that contributes to the development of processes to capture subjectivities (Alves, 2000) of current and future generations of workers. Given the subordinate way of inserting the Brazilian economy into the global capitalist system, within the overexploitation of work, the countries' bourgeoisie finds a way to compensate for the losses suffered due to a large amount of value it transfers to the central economies (Marini, 2000). For workers to continue to endure this intense exploitation of their workforce, through state mediation, national capitalists make use of a set of strategies that are not only repressive and political but also ideological, to subject workers to this process, among which education stands out.

Educational policies must be elaborated based on the needs of production, so they ensure the control of capital over labor. To this end, these policies must converge to the construction of forms of consciousness that reproduce capitalist social relations, i.e., the development of an education that works for the construction of conservative consensus. These consensuses are present in state bureaucracies and gain formal visibility in official documents, such as education plans, which guide the actions of governments at different levels. They set goals and objectives aligned with hegemonic interests and, therefore, constitute relevant sources of research about the programs to be adopted by governments in a variety of dimensions of social life. The next section presents reflections on the relationship between education and work based on the content of the National Plans of Education and similar documents analyzed in the research.

\section{The perspective of education for Brazilian workers, from the perspective of the representatives of capital}

The analysis focuses on the relationship between education and work, from the propositions present in the National Plans of Education, elaborated between 2003 and 2015. One premise observed in the analyzed documents was the achievement of a virtuous economic growth envisioned in the period when Workers' Party (PT) ruled the federal government. Unlike the expectations of the Brazilian left-wing forces, PT continued the macroeconomic policy of previous governments, and its government was based on the perspective of class conciliation (Hillesheim, 2016). Despite the continuation of the macroeconomic policy, the PT governments implemented a more progressive wage policy that resulted in some real gain for workers, increased credit to stimulate domestic consumption (which did not occur without stimulating practices that led to indebtedness), invested in infrastructure (which ensured a significant number of new jobs), as well as developed and expanded a set of welfare policies. It was considered as a democratic and popular government, able to combine economic growth and social justice. This set of propositions gave new breath to the economy, allowing the country to face more favorable conditions, at least in the first instance, toward the effects of the intensification of the world capital crisis (2008-2010). However, these conditions proved insufficient because of the prolongation of the global economic contraction. The problems arising from this program have triggered political events of high impact in recent Brazilian history, ranging from a legal-parliamentary coup to the election of a President who represents the most reactionary national forces.

Both the proposals contained in the National Plans of Education (PNEs) and the economic dynamics of the period had repercussions on the educational reality of the entire country. This becomes more plausible when considering the PNE's inductive nature in relation to the other federation units. Although this problem is not investigated further here, it is worth noting that this repercussion remains evident when analyzing the goals and objectives aimed at the formation of the workforce. 
At the national level, the PNE 2001-2010 emphasized that high school youth must have an education capable of enhancing the exercise of citizenship and ensuring professional qualification, regardless of whether they are inserted in the labor market. In this sense, education is understood as an instrument that allows young workers to seek wage improvements, as well as to acquire new technologies aimed at increasing productivity (Lei No 10.172, 2001). These promises have the power to materialize the capture of the subjectivities (Alves, 2000) of young workers, and are usually incompatible with each other. This is because, according to Harvey (2010), the measures taken to deal with the capitalist crisis are offensive to labor and workers' political organizations and, while they mobilize the surplus workforce, they adopt new technologies to reduce the use of living labor and the advancement of competition. Contrary to the result the PNE promised for the qualification of young workers, these measures implied a decrease in the value of wages worldwide and the formation of an increasingly disposable workforce, living in progressively precarious conditions (Harvey, 2010).

In short, PNE 2001-2010 understands formal education as an indispensable tool for youth employability, considering the demands placed on a constantly changing market. The plan works as a guideline, emphasizing an education that ensures the development of 'general' skills, which can be understood as abilities that transcend the requirements of the labor market. In this sense, the PNE points out the need for a balanced approach, between a technical and humanistic education. It establishes competencies to be built in the training process, particularly in high school:

self-learning; perception of social dynamics and ability to intervene in them; understanding of production processes; ability to observe, interpret, and make decisions; mastery of basic language skills, communication, abstraction; capacity to adopt ethical values of solidarity, cooperation, and respect for individual characteristics. (Lei No 10.172, 2001).

This conception was not much altered in the PNE for the next period, given that the expansion of the high school, especially in the federal system, occurred from a reformulation that aimed, at least formally, to articulate science, culture, and work.

Regarding higher education, the PNE 2001-2010 points to the need to expand access to university to young people in poverty. This access, however, was made possible through the commercialization of education with the increase of private capital investments in this sector (Lei No 10.172, 2001). This option largely determined the nature and perspective of higher education, strongly sensitive to labor market imperatives, which rendered the proposal to combine humanistic technical training virtually ineffective.

The analysis of the plan shows that the reality of Brazilian education and the advancement of this policy were related to the financial possibilities of the state, as well as to the management strategies the government adopted, guided by a perspective of 'counter-reform.' These strategies were supported by managerial assumptions that ignored that the equitable allocation of public resources in education must not be set by the financial possibilities of the state alone, but also by the political responsibility of the state to address educational inequalities, prioritizing the populations living in most impoverished regions of the country.

The same document defends the idea that the plan was not an educational program, but a far-reaching social program with educational criteria and should, therefore, be funded from sources other than those at the budget for education. It is important to stress that education is a collective responsibility of the state and society. Therefore, implementing education in all its complexity is a task that must involve different governmental agencies, which implies in coordination of different areas of the state structure and civil society organizations (Lei No 10.172, 2001).

The statement below highlights the relationship between education and work in the document analyzed, also mentioning the connection between education with other areas such as health, social services, justice, and citizenship:

MEC [Ministry of Education] must have a joint action with the Ministry of Labor, to prepare, train, and educate workers [emphasis added], using resources from the applied from the Workers Support Fund FAT. The same applies to social services and health, regarding early childhood education; Social services, concerning fighting poverty; the Ministry of Justice regarding the education of imprisoned and former convict youth and adults, using resources from the Penitentiary Fund (FUNPEN); to the Ministry of Communication, for the resources destined to universalization of education that should be made available in privileged conditions to public schools; for the Ministries of Culture; Sport and Tourism; Science and Technology and so on. Education is not a ghetto-confined concern of a segment. It involves the entire government and must permeate all its actions. (Lei No 10.172, 2001). 
This PNE was released under President Fernando Henrique Cardoso's government in 2007. President Luiz Inácio Lula da Silva's administration released a new document, the Education Development Plan (PDE)3. The PDE and the Plan of Goals - 'All for Education' Commitment (Decreto No 6.094, 2007), formed an executive plan articulated with a set of government actions in a larger plan: The Growth Acceleration Plan (PAC). When analyzing the PDE in the context of the Plan of Goals - 'All for Education' Commitment, Saviani (2007, p. 1233) considers that:

The PDE appears to be a broad umbrella program for virtually all initiatives carried out by the Ministry of Education. Apparently, in the event of the launch of the Growth Acceleration Program (PAC) by the federal government, each ministry would have to indicate the actions that would fit into that program. MEC then took the opportunity and launched the Basic Education Development Index (IDEB). The ministry connected all its activities to IDEB, adjusting and updating some of them. The activities cover all MEC's areas of influence, covering all levels and modalities of education, as well as complementary and infrastructure measures. The 30 actions presented as members of the PDE appear on the MEC website individually, listed without any grouping criteria.

In 2007, the Ministry of Education (MEC) prepared a publication entitled: Education Development Plan: motivation, principles, and programs (Ministério da Educação, 2007). In this publication, the federal government states that the PDE is an instrument to be used to implement the education project envisioned for the country. The document clarifies how the government understands education:

a part of the dialectical process that is established between socialization and individuation of a person. It aims to build autonomy, i.e., preparing individuals to be able to assume critical and creative positions in the world. Public formal education is the state's share of responsibility for this broader social effort, which not only takes place in the public school, but also in the family, the community, and every form of interaction in which individuals take part, especially in work [emphasis added]. The public school and, on a more general level, the national education policy, requires forms of organization that favor autonomy-oriented individuation and socialization. (Ministério da Educação, 2007, p. 05).

Thus, the PDE should contribute to fulfilling the objectives outlined in the 1988 Brazilian Federal Constitution, especially those related to the eradication of poverty and the reduction of social inequality (Constituição da República Federativa do Brasil, 2019). The proposal appears to be based on the idea that the increase in education quality is related to the possibilities of economic and social development. According to the Ministry of Education this is because "the link between education and development is essential insofar as it is through development that one can recognize and constitute the interfaces between education as a whole and the other areas of the state's activity.” (Ministério da Educação, 2007, pp. 06-07). Therefore, the PDE is based on the systemic idea of education, in which its structure and operation point to a unit that integrates the initiatives of "daycare to graduate" (Ministério da Educação, 2007, p. 10), organized from programs that refer to "four guiding axes: basic education, higher education, vocational education, and literacy". (Ministério da Educação, 2007, p. 15).

The PDE guided the actions of the federal government from 2007 until the publication of the new PNE, for the period from 2014 to 2024. It is worth to clarify some aspects of the process of the new PNE in the Brazilian Congress since this process reveals essential nuances about the economic, political, and cultural dynamics of the country.

In a document prepared by the Congress after the appraisal of the PNE, the plan was referred to as "strategy for the country," and education is expressed as a state policy, requiring "systematic and long-term planning "(Lei No. 13.005, 2014, p. 15). It states that "planning is a political process, as it involves decisions and negotiations about the choice of goals and ways to achieve them." (Lei No. 13.005, 2014, p. 10).

The executive branch sent the PNE 2014-2024 to Congress in December 2010, and the final document was approved only in 2014, i.e., there was a time gap between the end of the previous PNE and the start of the plan 2014-2024. To avoid this gap occurring again, the legislation that established the current PNE provides that the bill with the proposal for the next period will be sent to the Congress by the end of the first semester of 2023 (Lei No. 13.005, 2014).

The document from the Congress considers that establishing the PNE through legislation (it was the second time in history that this happened) was an advance. It highlights that the investments in education established in the plan (10\% of the GDP) is an important achievement of Brazilian society (Lei No. 13.005, 2014). The Congress stresses that compliance with the PNE must be continuously monitored and periodically 
evaluated by the government authority (MEC), the education commissions of the Congress, and the National Education Council (CNE) and the National Forum of Education (FNE) (Lei No. 13.005, 2014). The legislation process in Congress was marked by controversies. Among the main issues was the wording of goal twenty of the plan, which arrived in the Chamber of Deputies saying "[...] expanding public investment in public education to reach, at least, the level of seven percent of the GDP in the fifth year of this law and at least the equivalent of ten percent of GDP by the end of the decade." (Lei No. 13.005, 2014, p. 21).

In the Senate, a new text replacing the original was presented, removing from the text the expression "public," making additions and changes in article $5^{\circ}, \S 5^{\circ}$, of Law 13005 of 2014 (legislation that established the PNE). At the end of the process, the altered wording regarding Goal 20 was approved, as well as the provisions of article $5^{\circ}$, $\S 5^{\circ}$, of the law establishing the plan (Lei No. 13.005, 2014). Therefore, it was possible to consider as public investment in education the resources allocated through tax exemptions, which finance programs such as the University For All Program (ProUni) and the National Program for Access to Technical Education and Employment (Pronatec), as well as loans granted through the Student Financing Fund (FIES).

In the document presenting the PNE 2014-2024, issued by the Chamber of Deputies, there was a controversy regarding the guideline on overcoming educational inequalities. In the Senate, a proposal was presented to amend the text of the Chamber that provided for the promotion of "racial, regional, gender, and sexual orientation equality" (Lei No. 13.005, 2014, p. 22). In the legal text, the idea prevailed that the guideline should aim at "overcoming educational inequalities, with an emphasis on promoting citizenship and eradicating all forms of discrimination," as provided for in article $2^{\circ}$, item III, of Law 13005 of 2014 (Lei No. 13.005, 2014).

The set of goals identified in the PNE 2014-2024, approved by Law 13005 from June 25, 2014, maybe separated in large blocks, according to the MEC. The first refers to "structuring goals" that guarantee the right "to quality basic education, which concerns access, universalization of literacy and expansion of schooling and educational opportunities" (Ministério da Educação, 2014, p. 09). Among these goals stand out Goal 10, which provides offering "at least, $25 \%$ (twenty-five per cent) of the places for young people and adults in elementary and secondary education, as part of vocational education;" and Goal 11, which triples the "secondary vocationaltechnical education enrollments, ensuring the quality of supply and at least $50 \%$ (fifty per cent) of expansion in public education" (Ministério da Educação, 2014, p. 10). The second block of goals is related to "the reduction of inequalities and the appreciation of diversity", which, according to the federal managing body for education, constitute "indispensable paths to equity" (Ministério da Educação, 2014, p. 11). Goal 8 stands out in this group, providing on the elevation of the "average schooling of the population from 18 (eighteen) to 29 (twenty-nine) years, in order to reach at least 12 (twelve) years of study in the last year of this plan, for the rural populations, the region with the lowest education in the country, and the poorest $25 \%$ (twenty five percent), and to equal the average education between blacks and non-blacks as declared to the Brazilian Institute of Geography and Statistics - IBGE" (Ministério da Educação, 2014, p. 11). Finally, another block of goals aims at "valuing education professionals." Such valuation is "considered strategic for achieving the previous goals" (Ministério da Educação, 2014, p. 12). These goals are related to the education, career, and remuneration of teachers, and the provisions are considered as a strategy able to change the reality of the professionals working as teachers in different levels of education.

The executive branch, through the MEC, in the document entitled Planejando a Próxima Década: conhecendo as 20 metas do Plano Nacional de Educação (Planning the Next Decade: Knowing the 20 goals of the National Plan of Education), states that:

The complexity of the Brazilian federative model, the gaps in the regulation of cooperation norms, and the patrimonialist view that still exists in many sectors of public management make the task of educational planning quite challenging. Planning in this context implies making commitments to the ongoing effort to eliminate historical inequalities in Brazil. This requires a new attitude: building organic forms of collaboration between education systems, even if the rules for federal cooperation are still not yet established. (Ministério da Educação, 2014, p. 5).

At that time, the Ministry of Education considered that the elaboration of a PNE in Brazil implied the assumption of commitments and continuous efforts to eliminate historical inequalities in the country. In this sense, according to the government:

the goals aim to face barriers to access and permanence in schools; fight educational inequalities in each territory focusing on the specificities of local populations; preparing for work [emphasis added], identifying the potentialities of local dynamics; and practicing citizenship. (Ministério da Educação, 2014, p. 09). 
By pointing out the strategies for the achievement of Goal 11, which triples the enrollment for vocationaltechnical education at high school level, in the federal system of professional, scientific, and technological education, the PNE 2014-2024 legislation states the intention to "reduce ethnic-racial and regional inequalities in access to and retention in secondary vocational-technical education [emphasis added], adopting affirmative policies, in accordance with the law" (Lei No 13.005, 2014).

It is worth mentioning that the goal of expanding investment in public education, aiming to reach the minimum percentage of 7\% (seven percent) of the country's GDP by the 5th (fifth) year of the PNE 2014-2024 and, at least, the equivalent of $10 \%$ (ten percent) of GDP at the end of the decade (Goal 20), is at risk due to the impacts of the slowdown of the country's economic growth, not fully assessed when drafting the plan. Moreover, the approach toward education observed in President Michel Temer's government and the current President Bolsonaro's administration, investments in this area will be conditioned to the interests of economic groups, especially those companies operating in the field of education.

\section{[...] from the workers' point of} view, an education that

\section{confronts what is established}

and supports the programmatic actions of organizations

representing the class may and

must be born, evolving in the

political struggle based on the

assumptions and foundations of

the critical political economy

inaugurated by Marx [...]

The analysis of the contents of the documents mentioned above (and other documents of the federal government that could not be described in this article, especially the Multiannual Plans for the period 2003-2015), show an effort to update and strengthen education as an indispensable mediation to forge the profile of the current and future workforce.

The content of all these documents shows that the relationship between education and work is one of the most outstanding aspects in the debate about what is expected from Brazilian education. Although the statement about the education's objective to form students' critical consciousness toward social reality, the education's usevalue by capital is revealed in the conformation of the workforce to meet the demands of the labor market. And, in turn, the productive inclusion of the children of both rural and urban poor workers, enhanced by education, appears in this context as the alternative to guarantee their exercise of citizenship. This challenge imposes a regime of collaboration to conduct the policy, not only among the entities of the federation, but involving with the private sector and with a wide range of civil society organizations. The expansion of vocational and technical education for youth and adults at the high school level, as well as the expansion of access to higher education, increasingly specialized and accelerated to meet the demands of the labor market, appears as a central goal, in all levels of planning. This calls for more flexible curriculum organizations that rapidly meet the demands of this market, while having content able to develop skills, competencies, and values compatible with bourgeois society. Thus, there is the appreciation of the culture of entrepreneurship, pragmatic knowledge, autonomy - always from an individualistic perspective competitiveness, emotional/affective potentialities, initiative and responsibility with processes, and teamwork. All values that translate part of the capital project for young people from the working class, especially from poorer areas who must have a worldview converging with the existing productive structure. This is because the expansion of capital is not restricted to the sphere of production, where the direct relationship between capital and labor is processed, but also extends to the sphere of social reproduction, within politics and ideology. And in this direction, education as a state policy must forge attitudes and behaviors that are compatible with increasingly precarious living and working conditions in the context of flexible accumulation. The educational processes that occur, especially within formal education systems, are therefore essential for capturing the subjectivity (Alves, 2000) of young workers. The advance of private interests in the field of public education is seen in this relationship between education and the labor market, either in defining the content of training or in the participation of educational companies in implementing training and vocational education. In higher education, for example, the principle of university autonomy is reduced to financial autonomy, ensured through the establishment of partnerships with the productive sector that, when financing projects, subjects the production of knowledge to the strict interests of this sector, to the detriment of needs of society as a whole. Regarding vocational education, despite the growth of places in public institutions observed in the period analyzed, the long-term orientation of the 
World Bank is that this type of education is carried out by private organizations. In a document prepared in 1995, the World Bank (1995, p. 40) argues that:

\begin{abstract}
Enterprise-led training is usually the most cost-effective means of developing worker skills. By comparison, government delivery in most countries, in state-sponsored training centers and especially in vocational education, has proved expensive and often has provided trainees with few marketable skills. Ways must be found to reorient public training institutions to respond to consumer and market demands. The best way is often to shift public financing from providers of training to the demand side of the market enabling targeted workers to purchase training within a competitive environment of alternative suppliers [emphasis added].
\end{abstract}

The control of knowledge-producing and reproducing institutions can never be neglected by capitalists, given their need to make their thinking hegemonic and assimilated by the economically exploited and politically dominated classes. Education, therefore, has undisputed importance. Dominant thought is not only dominant because it belongs to the ruling classes, but because they are inserted "in historically determined social relations of production that place them in the role of domination." (Iasi, 2013, p. 70). In this sense, the reflections on education lead to the analysis of ideologies, understood not as separate from material conditions, but as an expression of them, in a permanent dialectical movement. The ideologies are capable of softening, controlling, or postponing the conflicts that are characteristic of the dynamics around social classes.

\title{
Final considerations
}

The data collected in the research indicate a resumption of an educational perspective that, although disguised by a discourse based on the defense of citizenship and law, is centered on the ideological, political, technical, and cultural conformation of the workforce. This perspective is in line with the demands of an increasingly selective labor market, structured and streamlined by the adoption of new technologies. The propositions observed in the plans point to the dissemination and assimilation of values and behaviors aligned with the flexible accumulation model. The plans also advocate for the technical preparation of workers based on operational knowledge. This type of education in and through alienated and alienating work denies the worker the construction of knowledge that allows them to control production and advance towards new sociability in which they are educated in and through work as a self-activity, a work that supports and enables the development of one's social being. Most workers, especially young people, will not be able to form the overqualified group of professionals that the labor market demand. Therefore, other critical dimensions of education do not go unnoticed in the propositions outlined by capital to (de)form the workforce: the stimulus to incorporate the culture of entrepreneurship, individualism, and the cult of autonomy reduced to the ability to create alternatives for survival that are independent of state policies. There are challenges to be faced by the class through their political organizations, which indeed constitute educational spaces.

It is appropriate to mention the intensification of attacks on public education policy at all levels promoted by President Jair Messias Bolsonaro's government. Since his inauguration as President, there have been programmatic activities that align the interests of businesses operating in the field of education and some religious traditions, which aims at making education an even more profitable commodity, at the same time as making schools and universities places free of an alleged "leftist ideological indoctrination." In this context, there is an advance of conservative thinking that slows down the process of constructing class consciousness, a fundamental aspect in triggering structural social transformations.

\section{References}

Alves, G. (2000). O novo (e precário) mundo do trabalho: Reestruturação produtiva e crise do sindicalismo. São Paulo, Brazil: Boitempo.

Camini, L. (2010). A política educacional do PDE e do Plano de Metas Compromisso Todos pela Educação. Revista Brasileira de Política e Administração da Educação, 26, 535-550. Retrieved from: https://seer.ufrgs.br/rbpae/issue/view/3768

Constituição da República Federativa do Brasil (1988) (2019). Retrieved from: http://www.planalto.gov.br/ccivil_03/Constituicao/ ConstituicaoCompilado.htm

Decreto No 6.094, de 24 de abril de 2007, Diário Oficial da União [D.O.U] de 24.4.2007. Retrieved from: http://www.planalto.gov.br/ ccivil_03/_Ato2007-2010/2007/Decreto/D6094.htm 
Harvey, D. (2010). Organizando para a transição anticapitalista. In A. G. Linera (Ed.), Margem Esquerda: Ensaios marxistas (pp. $57-$ 80). São Paulo, Brazil: Boitempo.

Hillesheim, J. (2016). Conciliação trabalhista: ofensiva sobre os direitos dos trabalhadores na periferia do capitalismo. Rio de Janeiro, Brazil: Lumen Juris.

Iasi, M. L. (2013). Educação e consciência de classe: desafios estratégicos. Perspectiva, Florianópolis, 31, 67-83. doi: 10.5007/2175795X.2013v31n1p67

Lei No 10.172, de 9 de janeiro de 2001, Diário Oficial da União [D.O.U] de 10.1.2001. Retrieved from: http://www.planalto.gov.br/ ccivil_03/leis/leis_2001/110172.htm

Lei No. 13.005, de 25 de junho de 2014, Diário Oficial da União [D.O.U] de 26.6. Retrieved from: http://www.planalto.gov.br/ccivil_03/ _ato2011-2014/2014/lei/113005.htm

Lukács, G. (2013). Para uma ontologia do ser social II [Toward the ontology of social being II] (N. Schneider, Trans.). São Paulo, Brazil: Boitempo,

Marini, R. M.(2000). Dialética da dependência. Petrópolis, Brazil: Vozes; Buenos Aires, Argentina: Conselho Latino-Americano de Ciências Sociais.

Marx, K. O capital: Crítica da economia política: Livro I: o processo de produção do capital. [Capital: Critique of political economy: Book I: The Process of Production of Capital] (R. enderle, Trans.). São Paulo, Brazil: Boitempo.

Ministério da Educação. (2014). Planejando a próxima década: Conhecendo as 20 metas do Plano Nacional de Educação. Retrieved from: http://pne.mec.gov.br/images/pdf/pne_conhecendo_20_metas.pdf

Ministério da Educação. (2007). Plano de Desenvolvimento da Educação: razões, princípios e programas. Retrieved from: http://portal.mec.gov.br/arquivos/livro/livro.pdf

Saviani. D. (2007). O plano de desenvolvimento da educação: análise do projeto do MEC [Special issue]. Educação \& Sociedade, 28, 1231-1255. doi: 10.1590/S0101-73302007000300027

World Bank. (1995). World Development Report 1995: Workers in an integrating world. New York: Oxford University Press.

\section{Notas}

1 The research Educação, pobreza e desigualdade social (Education, poverty, and social inequality) is part of an initiative with the same name, funded by the Secretary of Continuing Education, Literacy, diversity, and Inclusion of the Brazilian Ministry of Education(SECADI/MEC). The research studied the period between 2003 and 2015, based on the following documents: Multiannual Plans, National Plan of Education, National Curriculum Guidelines (Federal Government; Multiannual Plans, Education Plans, and Curricular Proposals of the state of Santa Catarina (State Government); Multiannual Plans, Education Plans, and Curriculum Guidelines of 12 municipalities located in 6 mesoregions (Local Governments); and the Political and Pedagogical Projects of 12 schools located in the selected municipalities.

2 According to Lukács (2013, p. 384), "the more developed, the more social is an economic education, the more complex the mediation systems within it; these systems interact with the man's self-reproduction, his metabolism with nature, and are related to him and built in such a way that they influence him both to promote or to inhibit him."

3 PresidentLula da Silva's government received from President Cardoso's administration a long-term and complex reform on education." Cardoso's government, "during the two terms of office, changed the direction of Brazilian education from basic to higher education, leaving [to the next government] as an alternative "to reform education or preserve and maintain the previous projects" (Oliveira, 2009, p. 198)" (Camini, 2010, p. 538). The plan of President Lula da Silva's government was intended to last for fifteen years after its implementation in 2007. The plan's content anchored in six pillars: systemic view of education, territory, development, collaboration, accountability, and social mobilization. In short, the actions envisaged in the PDE are the following: quality index; the exam called "Provinha Brasill"; School transportation; the initiative "gosto de ler"(I like reading); Brasil alfabetizado (Brazil literate); luz para todos (electricity for all); wage floor for teachers; teacher training, high-education, easy access to university; library in schools; professional training; internship; professional education; child care; multifunctional rooms; post-doctorate; census through Internet; health in schools; Olhar Brasil (a look at Brazil); Mais Educação (more education); special education; professor-equivalente (new position in teaching career); technology guide; Coleção educadores (collection of books on education); dinheiro na escola (cash transfers to schools); exam to hire new teachers; accessibility; cidades-polo (larger cities receive education infrastructure to serve a region of the states); digital inclusion.

\section{Jaime Hillesheim}

jaime.h@ufsc.br

PhD in Social Work from the Graduate Program in Social Work of the Federal University of Santa Catarina (UFSC). Professor at the Department of Social Work of the UFSC 


\section{Adir Valdemar Garcia}

adir.vg@ufsc.br

$\mathrm{PhD}$ in Political Sociology from UFSC. Professor at the Department of Specialized Studies in Education of the School of Education Sciences of the UFSC.

\section{UFSC}

Campus Universitário Reitor João David Ferreira Lima - Trindade

Florianópolis - Santa Catarina - Brasil

CEP: $88.040-900$

\section{Acknowledgement}

We are grateful to Professor Tânia Regina Krüger her support during the development of the research on education, poverty, and social inequality.

\section{Financial support}

National Fund for Educational Development (FNDE) and Secretary of Continuing Education, Literacy, Diversity, and Inclusion of the Ministry of Education (SECADI/MEC). Agreement no 1949/2014.

Term of agreement: June 13, 2014 to December 31, 2017.

\section{Contributions of authors}

Both authors contributed decisively in the elaboration of this article, which is a product of the research Education, pobreza e desigualdade social (Education, poverty, social equality) carried out by the authors with Professor Tânia Regina Krüger.

Approval by the Ethical Committee and consent to participate

Not applicable.

\section{Consent to publish}

Not applicable.

\section{Conflict of interest}

Not applicable. 